\title{
Kim (czym) jest zwierzę i kto (co) jest zwierzęciem? Garść uwag językowych
}

Słow a klucze: semantyka; fenomenologia lingwistyczna; rzeczownik; zwierzę

Key words: semantics; linguistic phenomenology; noun; animal

\section{Wstęp}

Myślę, że nikt (na dobrą sprawę) nie stawia sobie tego rodzaju pytań jak te, które pojawiły się w tytule. Przecież wszyscy dobrze wiemy, kim lub czym jest zwierzę. Czy potrafilibyśmy jednak podać definicję wyrazu zwierzę, czy jesteśmy w stanie wyliczyć wszystkie istoty, które prawdziwie i bez reszty podpadają pod tę nazwę i czy wreszcie (co z mojego punktu widzenia wydaje się najważniejsze) nie żywilibyśmy żadnych wątpliwości, włączając do tej klasy jedne organizmy, a wykluczając z niej inne? Do tych wątpliwości dodam jeszcze kilka innych, które od niedawna zaprzątają moją uwagę: czy zwierzę jest kimś, czy też raczej czymś; czy zwierzę to tylko organizm, czy może już istota albo wręcz osoba - i bodaj najważniejsze: kto (lub co) jest zwierzęciem, a kto (lub co) - już nie? Wierzę głęboko w to, że z czasem wła- 
śnie w języku (w mowie) znajdę odpowiedzi na te oraz inne nurtujące mnie pytania ${ }^{1}$.

\section{Biologiczna i lingwistyczna systematyka organizmów}

Świat przyrody ożywionej urzeka swoją różnorodnością (tak w skali makro-, jak i mikro-). Systematyka organizmów jest dyscypliną biologiczną, która stawia sobie za cel identyfikację i klasyfikację wszelkich przejawów życia. Na gruncie tej gałęzi przyrodoznawstwa podejmuje się próby stworzenia taksonomii organizmów żywych (m.in. w oparciu o wyniki badań, jakich dostarczają anatomia, embriologia i genetyka, a więc na podstawie ogólnego planu budowy, sposobu rozmnażania i danych molekularnych). Na obszarze badań taksonomicznych zakłada się, iż istnieje na Ziemi hierarchia jednostek systematycznych, por. królestwo, gromada, klasa, rząd, rodzina, rodzaj, gatunek, podgatunek, rasa, odmiana, forma, linia, szczep, klon. Chociaż sformułowano szereg propozycji taksonomicznych, nie istnieje aktualnie jedna, powszechnie przyjęta i ogólnie akceptowana klasyfikacja (szerzej na ten temat Mayr 2002: 103-121).

W tym miejscu, w sposób naturalny, nasuwa się pytanie: co nowego i wartościowego może wnieść do tej profesjonalnej i toczącej się od lat debaty miłośnik języka i zarazem humanista? Uważam, że prace semantyczno-lingwistyczne nie mają na celu wytyczania nowych dróg w naukach biologicznych; w gruncie rzeczy jednak semantyk rozprawia o tym samym co zoolog - tyle że z nieco innego, właśnie językowego punktu widzenia. Siłą rzeczy niniejsza praca sytuuje się w obrębie etnobiologicznie zorientowanej semantyki, co znaczy, iż w kolejnych akapitach podejmę próbę rozwiązania pewnych kwestii filozoficznych za pomocą narzędzi językoznawczych. Ponieważ jednak artykuł ten ma charakter rekonesansu, ograniczę się tylko do wstępnej charakterystyki ograniczeń selekcyjnych, jakie wybrane predykaty (czasowniki) narzucają niektórym nazwom istot żywych. „Gwiazdka” (*), jaką opatruję część przykładów, sygnalizuje - w moim zamyśle (i zgodnie z moją intuicją) - niekompatybilność (semantyczną, gramatyczną, a nawet pragmatyczną) znajdujących się w przykładach kookurencji (z grubsza więc podkładam

1 Naturalnie, pytania takie stawiali już przede mną (wielokrotnie) inni badacze, por. Bogusławski 1996a: 109-142; 1996b: 1-38; 1997: 103-129; 2001: 209-245; 2002: 1-30; 2004: 1-26; a już zwłaszcza: Bogusławski 2007. 
pod sporną gwiazdkę ocenę w rodzaju: Tak bym nie powiedziat.). Do kwestii dewiacyjności przywoływanych przykładów podchodzę zatem (na tym etapie badań!) bardzo szeroko. W przyszłości chciałbym jednak nadać swoim rozważaniom kształt metodologicznie bardziej wyrazisty i merytorycznie bardziej rygorystyczny.

\section{Zwierzę jako termin naukowy i wyrażenie językowe}

W języku, jak powszechnie wiadomo, można odnaleźć potoczne teorie rzeczywistości, np. ślady arystotelesowskiej metafizyki, euklidesowej geometrii, newtonowskiej mechaniki oraz linneuszowskiej systematyki (taksonomia Arystotelesa, tj. partycja organizmów na królestwa: zwierząt i roślin, nie przystaje, jak się niebawem okaże, do portretu, jaki kreśli język). W tym miejscu w sposób naturalny wyłania się więc zasadnicze pytanie: jak dotrzeć do pojęciowych (etnobiologicznych) zrębów świata, jakie sugeruje w swojej mądrości język, albo też inaczej: jakie elementy języka (systemu) należy wziąć pod uwagę, chcąc zrekonstruować utrwalony w mowie portret zwierzęcia (czy też może szerzej: żywego organizmu, ale nie-człowieka i nie-rośliny)? Przede wszystkim należy wziąć pod lupę przykłady użycia nazw istot (stworzeń) we właściwych im kontekstach - w pozycjach implikowanych przez swoiste dla nich (wszystkich razem i poszczególnych z osobna) predykaty.

Życie organizmów relacjonują ,predykaty witalne”, tj. te spośród orzeczeń, które otwierają pozycje semantyczno-syntaktyczne dla nazw jakichś organizmów: w roli agensa lub adresata. Termin predykaty witalne obejmuje swoim zakresem podklasę orzeczeń, które nazywają takie cechy i stany, czynności i procesy, które charakteryzują (na najwyższym poziomie ogólności) organizmy żywe. Wierzę w to, że wiązki typowych dla poszczególnych gatunków predykatów pozwalają się na tyle uogólnić, że można (na podstawie ich hiperonimów) stworzyć językowy portret organizmu (oraz życia jako takiego), kierując się jedynie tymi ich wykładnikami, które podpowiada w swojej mądrości nieomylny język, a więc bez uwzględniania wiedzy naukowej (encyklopedycznej). Na przykład: uogólniając hiponimy i troponimy predykatów witalnych, można zaryzykować stwierdzenie, że organizmy żyją w taki sposób, że: rodzą się i rozwijają, odżywiają się i oddychają, komunikują się i rywalizują, rozmnażają się i umierają. Natomiast żyjąc, coś wiedzą 
i coś robią, zwłaszcza coś właściwego tylko sobie (jako przedstawicielom odrębnych klas).

Najlepiej chyba jednak będzie, gdy zacznę od tego, że ciąg zwierzę funkcjonuje obecnie w języku polskim jako z jednej strony, wyrażenie językowe i, z drugiej strony, termin naukowy, denotując odpowiednio dwie zakresowo różne klasy zwierząt: w sensie węższym (wyrażenie), zob. (1) i (2), oraz szerszym (termin), zob. (3) i (4):

(1) Na śniegu krzyżowały się ślady ludzi i zwierząt.

(2) Błyszczqce futerko świadczy o tym, że zwierze jest zdrowe.

(3) Człowiek zajmuje w królestwie zwierząt szczególne miejsce.

(4) Pantofelek to zwierze jednokomórkowe.

Co interesujące, język potoczny podąża w tym względzie za tradycją biblijną, zgodnie z którą zwierzęta (w sensie węższym) odróżnia się zarówno od ludzi, jak i od innych gatunków (tych zwłaszcza, które systematyka biologiczna włącza w obręb królestwa metazoa, a więc zwierząt w sensie szerszym), por. I stworzyt Bóg ptaki, ryby i zwierzęta.

Po pierwsze więc, uważam, że taksonomia językowa powinna uwzględniać tylko jednostki języka (tj. wyrażenia językowe w przeciwieństwie do terminów naukowych), które nazywają organizmy. W tym duchu pragnę przypomnieć, że język potoczny najczęściej „nie akceptuje” (ze względów stylistycznych) naukowych wtrętów, zwłaszcza w kwestii nominacji językowo realnych klas gatunków, np.:

(5) *Po podwórku biega jakiś ssak. (pies)

(6) *W trawie znaleźliś́my kilka płazów. (żab)

(7) *Brzegiem rzeki kroczyt olbrzymi skorupiak.(rak)

(8) *Spod liścia wypetznat malutki mięczak. (ślimak)

(9) *Pod okapem misternie przędzie swoja sieć stawonóg. (pająk),

wobec:

(10) Wieczorem pod dom podchodziły zwierzęta.

(11) W głębinach mórz żyja różne gatunki ryb.

(12) Przez uchylone okno wleciało kilka owadów. 
(13) Nad naszymi głowami fruwaty spłoszone ptaki.

(14) Po posadzce petzną odrażajacy robak.

Po drugie, każde wyrażenie powinno zostać skontrastowane z innymi tak, aby można było je łączyć w klasy o identycznych własnościach, a przy tym w taki sposób, by stwarzało to szansę przewidywania (dedukowania) ich gatunkowo istotnych cech.

Taksonomia językowa, czyli klasyfikacja organizmów, osobliwie - istot żywych (stworzeń bożych), znajdująca swoje oparcie w danych, które płyną z języka, obejmuje jedynie niektóre gatunki spośród ogółu tych, jakie zwykle wyodrębnia się na gruncie biologii systematycznej, por. zwierzę, ptak, ryba, owad, robak, zarazek, komórka; inne reprezentują przedstawiciele niższych taksonomicznie jednostek, np. żaba (płaz), rak (skorupiak), pajakk (pajęczak), ślimak (mięczak). Kolejnym gatunkom (i ich reprezentantom) przysługują odrębne, ale krzyżujące się podzbiory predykatów. W języku można zatem (w oparciu o te orzecznikowe dystynkcje!) wyodrębnić spektrum gatunków wraz z typowymi dla nich własnościami. Sprawa ta wymaga jednak dokładniejszego zbadania (tej kwestii zamierzam poświęcić odrębne publikacje).

Jestem zdania, że język dobrze przyswoił sobie pojęcie gatunku jako zbioru organizmów (zarówno ich przodków, jak i potomków), które są do siebie podobne i które mogą się ze sobą rozmnażać (są więc w stosunku do innych odrębne i w relacji do siebie tożsame). Wyrażenie gatunek jest zatem intuicyjnie zrozumiałe, a przy tym najbliższe potocznej mowie, zwłaszcza w zderzeniu z nazwami pozostałych jednostek taksonomicznych. Ponadto, w charakterystyce gatunku ujawnia się (dochodzi do głosu) esencjonalna myśl, która przenika ludzkie poznanie (na wskroś), czego konsekwencję stanowi, zadomowiona już w literaturze, dystynkcja między pojęciami naturalnymi i kulturowymi (więcej na ten temat w: Grochowski 1993 oraz Gleason, Ratner 2005). Treści pojęć naturalnych wyjaśnia się, uwzględniając wewnętrzne (obiektywne) struktury ich desygnatów ${ }^{2}$, z kolei treści pojęć kulturowych określa się, biorąc pod uwagę ich zewnętrzne (subiektywne) funkcje:

${ }^{2}$ Gatunek naturalny, podobnie jak imię własne, kwalifikuje się jako sztywny desygnator, tj. nazwę, która odnosi się do tego samego przedmiotu (a także do przysługujących mu z konieczności cech) we wszystkich możliwych światach, w których przedmiot ten istnieje. W obydwu wypadkach (i imion, i gatunków) istnieje konieczność metafizyczna, a więc istotny związek między językiem i rzeczywistością (mianowicie dzięki 
(15) Widelec jest to rzecz zrobiona (przez ludzi) po to, żeby...

(16) *Kot jest to istota żywa, stworzona (przez Boga) po to, żeby...

Nazwy istot żywych należałoby przeto definiować, docierając do ich cech istotnych, tj. takich, które można „wytrącić”, posiłkując się testem sprzecznościowym (ze spójnikiem ale); nazwy organizmów można również eksplikować (choć nie stanowi to przedmiotu moich dociekań w tej pracy), odkrywając ich cechy asocjacyjne, które z kolei pozwala odnaleźć test konotacyjny (ze spójnikiem chociaż); składniki skojarzeniowe nierzadko zdają sprawę $\mathrm{z}$ ról, jakie człowiek wyznacza zwierzętom i roślinom, np. zwierzę hodowlane, pociagowe, wobec: ladowe, wodne.

\section{Czym jest organizm?}

Jak zwykle w takich sytuacjach w pierwszym rzędzie zachodzi paląca potrzeba eksploracji zakresu zaimka ktoś pod kątem jego zdolności substytucyjnych. Samoistnie nasuwa się zatem pytanie o nazwy bytów, które można podstawiać pod rzeczony zaimek? W pierwszym rzędzie nasuwają się takie propozycje, jak: byt absolutny (Bóg), byty realne żywe (człowiek, zwierzę, roślina), ale też różnego autoramentu byty intencjonalne i myślne (w tym postaci literackie). Głównie jednak będą mnie interesować, w kontekście substytucyjnego zakresu zaimka ktoś, nazwy żywych organizmów, zwłaszcza istot żywych (stworzeń bożych): ich wzajemne relacje oraz hierarchia, jaka między nimi obiektywnie istnieje. Jak dotrzeć do zajmujących mnie tutaj pojęciowych dystynkcji?

W zbiorze wszystkich predykatów daje się wyodrębnić podzbiór orzeczeń agentywnych, tj. takich, w których funkcję inicjalnego argumentu i zarazem wyrażenia tematycznego (tylko w wypowiedzeniach o neutralnej intonacji) odgrywa agens, który podpada pod zakres zaimka ktoś. Byty, jakie nazywają rzeczowniki, które wchodzą w zakres elementarnego zaimka ktoś, są (w wyborze i wielkim skrócie) jakieś i są gdzieś, bywają czyjeś i stają się jakieś, ale

stałości odniesienia przedmiotowego staje się możliwa identyfikacja bytów w różnych możliwych światach). Gatunki naturalne są to przede wszystkim nazwy zjawisk fizycznych, substancji chemicznych i, co szczególnie mnie zajmuje, gatunków biologicznych, których struktura wewnętrzna (wspólna wszystkim reprezentantom rodzaju naturalnego) stanowi istotę rzeczy, jaką relacjonują odpowiednie zdania koniecznie syntetyczne (na podstawie: Kripke 2006). 
przede wszystkim coś wiedzą: coś czują i czegoś chcą, a także coś robią, np. którędy (skądś i dokądś) się przemieszczają i coś do siebie mówią. (W swojej pracy oprę się na klasyfikacji orzeczeń, jaką zaproponowała Z. Zaron, zob. Zaron 2009: 52-88).

Myślę, że poza wszelką dyskusją sytuuje się twierdzenie, w myśl którego istnieje obszerna klasa predykatów-orzeczeń, które sensownie, tj. dosłownie i bezpośrednio, można orzekać o organizmach: zarówno wszystkich (hiperonimy), jak i niektórych (hiponimy i troponimy). Co z mojego punktu widzenia bardzo istotne, podzbiory predykatów, jakie można przypisywać najdosłowniej różnym gatunkom stworzeń i które zarazem akceptują w funkcji agensa nazwy istot żywych, wchodzą ze sobą w relacje teoriomnogościowe: iloczynu i różnicy, przy czym iloczyn ów obejmuje orzeczenia wspólne wszystkim organizmom, z kolei różnica - jedynie te, które są właściwe odpowiednim ich podklasom, czyli poszczególnym gatunkom. W ten oto sposób rysuje się szansa na uchwycenie zarówno tego, co stanowi inwariant 'bycia żywym organizmem', jak i nadzieja na wgląd w różnorodność fenomenu życia, która pociąga za sobą ustaloną hierarchię gatunków.

Człowiek od zarania dziejów dostrzegał jakościową różnicę pomiędzy tym, co jest żywe, a tym, co żywe nie jest. W jakiś niewytłumaczalny intuicyjny sposób ludzie zawsze czuli, czują i będą czuli, którędy przebiega granica między życiem i jego brakiem. Zagadnieniem równie fascynującym, co treść czasownika żyć, której poświęciłem odrębną publikację (Nowak 2012: 191-208), jest więc także - jego zakres, który wyznacza to, gdzie zaczyna się i gdzie kończy fenomen życia, a więc to, o kim można orzec, że żyje, a o czym - już nie.

Po pierwsze, warto na wstępie zakreślić granice tego, co żyje. Wyjdę od pewnej trywialnej obserwacji: otóż wszystko, co żyje, ogół organizmów, w bliższej lub dalszej przyszłości ginie. Uważam, że czasownik (z)ginqć to najogólniejszy (o najszerszym zakresie odniesienia) wyraz polski, który nazywa moment, w jakim ktoś, kto żyje (a taka porcja treści jest w przypadku tego wyrażenia presuponowana), przestaje żyć; najważniejsze jest jednak to, że orzeka się go tylko o organizmach żywych (i o nikim oraz niczym innym) - w postaci [ktoś] ginie/zginą $t^{3}$ :

3 W kontekście wielu wyrażeń, a już szczególnie tych, które odnoszą się do królestwa zwierząt i roślin, mogą się pojawiać raz po raz wątpliwości co do ich kwalifikacji jako kogoś lub czegoś (z przewagą raz jednego, raz drugiego). W takich spornych sytu- 
(17) Ludzie/zwierzęta/rośliny ginq.

(18) Niektóre wirusy gina w wysokich temperaturach.

(19) Plemniki w niesprzyjajacych warunkach szybko gina.,

wobec:

(20) *Bóg podobno zginqł w niewyjaśnionych okolicznościach.

(21) *Krasnoludki na pewno tragicznie zginęty.

Po drugie, nie wszystko, co żyje, rozmnaża się, jeżeli zaś się nie rozmnaża, a zarazem żyje, to pewnie jakoś reprodukcji jednak służy, co z kolei wyznacza dolną granicę bytów żywych:

(22) Jak się rozmnaża pantofelek?, wobec: *Jak się rozmnaża plemnik?

Sumując: organizm żywy jest jednak raczej kimś niż czymś (por. dosłowne ktoś żyje, wobec przenośnego: (to) coś żyje), w dodatku kimś, o kim można pomyśleć jako o kimś, kto żyje, m.in. dzięki temu, że można o nim powiedzieć, że ginie (zginął, zginie). Inaczej mówiąc: żywy organizm to ktoś, kto nieprzerwanie coś wie oraz coś robi (z kimś/czymś, za pomocąjakichś narządów, w jakimś miejscu itd.):

(23) *Ten pies żyje, ale niczego już nie wie i niczego już nie (z)robi.

Co istotne, organizmy nie wiedzą i nie mogą (zrobić) wszystkiego, ale nie jest też tak, że nie wiedzą oraz nie robią nic - te bowiem atrybuty (wiedza i aktywność) stanowią o istocie tego, co potocznie zwiemy życiem.

\section{Kim (czym) jest zwierzę i kto (co) jest zwierzęciem?}

Najogólniej rzecz biorąc, zwierzę (podpadając częściej pod zakres zaimka ktoś niż coś) jest stworzeniem (bożym): istotą żywą i żywym organizmem, w żadnym jednak wypadku - osobą albo duchem (czy duszą): 
(24) Zwierze to (̇̇ywy) organizm., por. organizm zwierzęcy, ale: *dusza zwierzęca, *osoba zwierzęca

(25) Zwierzę to jest stworzenie (boże).

(26) Zwierze jest istota (żywa).

W świetle ogólniejszych ustaleń, tj. odwołując się do przestrzeni logicznej, jaką wyznaczają możliwe kombinacje jednostek elementarnych typu: wiedzieć i zrobić, można zawyrokować, że zwierzę nie wie wszystkiego o wszystkim (i nie może zrobić wszystkiego ze wszystkim) - w przeciwieństwie do swojego Stwórcy:

(27) *Bóg wie i może wszystko, prawie tak jak wszechmocne zwierzęta, nie wspominajac już o wszechwiedzacych roślinach.

Zwierzę, w opozycji do człowieka, nie może także wiedzieć wszystkiego na jakiś temat (i nie może zrobić wszystkiego z kimś albo z czymś), co stanowi, jak sądzę, jedną z konsekwencji braku daru mowy:

(28) *Burek wie wszystko na temat obejścia swojej budy.

(29) *Burek wie wszystko o zawartości swojej miski.

Niewątpliwie jednak zwierzę coś o kimś lub o czymś wie, jak również coś z kimś lub z czymś nieustająco czyni (mianowicie zwierzęta, co dla nich wyróżniające, w kontraście do ludzi, nie mówią, ale z kolei, w opozycji do roślin, przemieszczają się: skądś i dokądś, a więc którędy, przy użyciu - co najistotniejsze - jakichś narządów lokomocji).

Klasa zwierząt nastręcza jednak nie lada kłopotów. Chodzi o to, że intensje oraz ekstensje wyrażenia i terminu zwierzę nie pokrywają się ze sobą, mianowicie termin naukowy zwierzę denotuje wiele różnych gatunków organizmów (kręgowców), m.in.: ssaki, ptaki, gady, płazy i ryby, podczas gdy jego językoznawczy odpowiednik, wyrażenie językowe zwierzę, desygnuje wąski zakres istot żywych, ograniczający się (w zasadzie) wyłącznie do gromady ssaków:

(30) W tym rejonie żyje kilka gatunków zwierzat i ptaków.

(31) *W lesie natrafiliśmy na sarny i zwierzęta. 
(32) *Dobrzy ludzie dokarmiaja zwierzęta, np. żaby $i$ węże.

(33) *Zima ludzie udzielaja schronienia zwierzętom, szczególnie robakom i owadom.

Warto pod tym kątem przyjrzeć się bliżej temu, jak zachowuje się leksem zwierzę, poddany testom (jednemu pozytywnemu i dwóm negatywnym, por. Markowski 1992), które „reagują” na wyrażenia utrzymane w tonacji innej niż wspólnoodmianowa (np. ekspresywne, specjalne i erudycyjne):

(34) Proszę pomyśleć o (tych) zwierzętach.

(35) *Jest to tak zwane zwierzę. oraz *Jest to, że się tak wyrażę, zwierzę.

Podsumowując: przedmiot moich dalszych dociekań będzie stanowił zadomowiony w mowie potocznej leksem zwierzę, który kwalifikuję jako leksykalną jednostkę języka: semantycznie niepustą, pełnoznaczną, złożoną i wyrażeniową.

Zwierzęta wiedzą i robią wiele różnych rzeczy: niełatwo w klasie charakterystycznych dla nich predykatów odnaleźć takie, które jednoznacznie wyodrębniałyby je z ogółu organizmów. Na wstępie, warto jednak zaprowadzić w licznej klasie organizmów jakiś względny porządek, ustalając przy okazji kilka podstawowych opozycji w zakresie tego, co zwierzęta (z natury swojej), w przeciwieństwie do innych bytów, wiedzą, a zwłaszcza, co robią.

Zarys językowej klasyfikacji organizmów, jaki proponuję, będzie się opierał na opozycjach prywatywnych, jakie ustalają treści dwóch predykatów: mówić i przemieszczać się, które poza swoistymi dla siebie rolami implikują semantycznie (tudzież inkorporują formalnie), funkcje narządów artykulacji i lokomocji. Wewnętrzny podział klas: ludzi, zwierząt i roślin będzie się odbywał na podstawie tego, jakie istnieją możliwości werbalnych realizacji kolejnych ról przy odpowiednich predykatach. Oczywiście, pewne funkcje są wyznaczone niejako na stałe, np. ludzie, w opozycji do zwierząt, mają narządy artykulacyjne, a zwierzęta, w opozycji do roślin, posiadają narządy lokomocyjne. Pozostałe funkcje różnicują natomiast klasy: ludzi, zwierząt i roślin na szczegółowe podklasy, które zostaną omówione w dalszej kolejności, np. czasownik mówić otwiera wokół siebie pozycje dla: agensa, adresata, tematu i obiektu, z kolei czasownik przemieszczać się implikuje role agensa i lokalizatora. Zarówno pozycje te, tak jak i funkcje realizują się rozmaicie, co su- 
geruje, że tradycyjnie wyodrębniane klasy (ludzie, zwierzęta i rośliny) są wewnętrznie zróżnicowane (do wątku tego powrócę jeszcze w innych pracach).

W świetle poczynionych uwag mogę orzec, że zwierzęta (sensu largo) przemieszczają się, ale nie mówią. Dokonując przeglądu ogółu predykatów witalnych, można dojść do wniosku, że tym, co odróżnia zwierzę od człowieka, jest to, że zwierzę nie mówi (o czym za chwilę), a tym, co odróżnia je od rośliny, jest to, że zwierzę się przemieszcza:

(36) Przez podwórko przebiegt wystraszony kot, zaraz za nim-pies, a na ostatek maty Adaś.

(37) *Przez podwórko przebiegło najpierw drzewo, a następnie kilka krzewów, a na koniec - kępa trawy.

Naturalnie, rośliny rosną: pną się (wspinają) lub płożą się (kładą), lecz nie przemieszczają się, zmieniając miejsce; są bowiem trwale przytwierdzone do podłoża.

Zwierzęta - takie, jakimi je portretuje język, czyli w sensie węższym przemieszczają się, prymarnie chodząc, biegając i skacząc po powierzchni ziemi (lub ryjąc pod jej powierzchnią), nigdy zaś - fruwając i latając w powietrzu czy też pływając i unosząc się w wodzie:

(38) Wieczorem pod dom przyszty/zbiegty się zwierzęta.

(39) *Wieczorem pod dom przyfrunęty/przyleciały/przypłynęty/przypetzty zwierzęta.

W moim przekonaniu, klucz do stworzenia językowo adekwatnego podziału klasy zwierząt stanowi wiwisekcja semantyczna pozycji oraz ról, jakie implikują predykaty motoryczne, w szczególności zaś - tzw. orzeczenia ruchu prostego. Najważniejszy w tej klasie predykat, czasownik przemieszczać się, otwiera wokół siebie pięć pozycji, przeznaczonych dla funkcji: agensa, miejsca i narządu, por. [ktoś] przemieszcza się [skadś'] [dokqudś] [którędy] za pomoca [czegoś]. Funkcje te ujawniają tkwiący w gatunkach i osobnikach potencjał: to, kim są, to, w jakim środowisku żyją, oraz to, jakimi zdolnościa- 
mi dysponują ${ }^{4}$ Istoty żywe przemieszczają się za pomocą czegoś lub kogoś: wykorzystując albo narządy (części ciała), albo organizmy (całe ciała): z jednej strony - własne kończyny (nogi, łapy, kopyta, racice i odnóża), skrzydła i płetwy, a z drugiej strony - odrębne istoty: własne bądź cudze. Dzięki tym udogodnieniom istoty żywe: chodzą, biegają, skaczą i pełzają po ziemi (a także ryją w ziemi), fruwają i latają w powietrzu, pływają i dryfują w wodzie, a także przenoszą się z organizmu na organizm lub też są z jednego na drugi przenoszone. Rzecz jasna, wszelkie ustalenia w tym względzie mają charakter pozytywny, co oznacza, że dotarcie do nich umożliwia kontrastowanie wyrażeń w opozycjach ekwipolentnych.

Mam podstawy, by przypuszczać, że miejsce, jakie zwierzę zajmuje na językowej drabinie bytów, wyznaczają też relacje, w jakich pozostaje ono do człowieka: zarówno na płaszczyźnie etycznej (moralnej), jak i (a może właśnie przede wszystkim) komunikacyjnej.

Po pierwsze, język odnotowuje fakt, iż między ludźmi i zwierzętami zawiązuje się swoista relacja, której istota wyczerpuje się w możności, co skrzętnie odnotowuje język, wyrządzenia zwierzętom (jako istotom odczuwającym) krzywdy5:

(40) dręczyćlmęczyćlskrzywdzić człowieka

(41) dręczyć/męczyć/skrzywdzić zwierzę

(42) *dręczyćlmęczyćlskrzywdzić roślinę

(43) *Adam skrzywdzit kure, przyrzqdzajac z niej rosót. ${ }^{6}$

(44) *Adam, przyjmujac lekarstwa, dotkliwie skrzywdzit kilka bakterii.

4 Język, co zresztą koresponduje z informacjami, jakie płyną z nauk przyrodniczych, kładzie akcent na anatomię, fizjologię i ekologię, eksponując takie wielkości, jak: narządy, czynności i nisze, jakie zamieszkują organizmy.

${ }^{5}$ Na marginesie: pragnę w tym miejscu zauważyć, że nawet pobieżny przegląd orzeczeń, które można orzekać o zwierzętach w roli obiektu (pacjensa), unaocznia los, jaki ludzie zgotowali swoim mniejszym braciom, „czyniąc sobie Ziemię poddaną”. Mam na myśli zadziwiająco sporą liczbę predykatów, które denotują rozmaite sposoby zabijania i oprawiania zwierząt.

${ }^{6}$ W tym kontekście należałoby się jednak zastanowić także nad zdaniami (być może właśnie akceptowalnymi) w rodzaju: Skrzywdził kurę, łamiqc jej skrzydło. oraz Skrzywdził muchę/biedronkę, wyrywając jej skrzydło. 
(45) *Adam, odrobaczając piwnice, skrzywdzit robactwo, które się tam zalęgło.

Po drugie, ludzie, roztaczając opiekę nad zwierzętami, a więc czyniąc je „swoimi”, biorą za nie też pełną odpowiedzialność:

(46) Pies Adama, ale: *Adam psa

(47) Tojest pies/papuga Ewy., ale: *Tojestżaba/owad/robak/bakteria Ewy.

Człowiek może bowiem zwierzę oswoić, a nawet - udomowić. Co ciekawe, do siebie oraz do swoich domów przyzwyczajamy nie tylko zwierzęta; oswajamy i udomawiamy też i ptaki, w żadnym jednak wypadku - inne organizmy:

(48) *oswoić/udomowić/tresować człowieka

(49) *oswoić/udomowić/tresować rośline

(50) *oswoić/udomowić/tresować węża/rybę/owada/robaka/bakterię

(51) oswoićludomowić zwierzę/.ptaka, por. także: gołab pocztowy, sokolnik

(52) poskramiacz zwierzat/*ptaków

(53) *oswojony/wytresowany waż/owad/robak/wirus

(54) *udomowiona/wytresowana ryba/dżḋownica/bakteria

(55) karmić zwierzęta/ptaki, ale: poić zwierzęta/*ptaki

(56) *karmić/*poić owady/robaki/wirusy ${ }^{7}$

Wierzę, że w niejednorodnej klasie zwierząt można wyodrębnić poszczególne jej piętra. Jeśli kryterium, które odróżnia zwierzęta od ludzi, jest ludzka mowa (i jej brak - w przypadku zwierząt), to rozsądne będzie uwzględnienie tego samego kryterium do wewnętrznej partycji zbioru zwierząt.

Ludzie, w przeciwieństwie do świata przyrody, nie tylko komunikują się ze sobą, ale także (a może: przede wszystkim) komunikują sobie coś, w tym na jakiś temat, tj. o czymś, innymi słowy, mówią:

${ }^{7}$ Można jednak oswoić węża, poić ptaki, karmić gady (np. w ogrodzie zoologicznym). 
(57) Burek szczeknat., wobec: *Adam szczeknqt.

(58) Burek szczeknat: hau!., ale: *Burek szczeknat-hau!, wobec: Adam szczeknat-odczep się.

(59) *Burek szczeknat, że hau., wobec: Adam szczeknąt, żebym się odczepit/że lepiej będzie, gdybym się odczepit.

Zwierzęta, co oczywiste, nie mówią: ani nie posiadają zdolności językowej, ani daru mowy:

(60) *Azor zakomunikowat coś Burkowi.

(61) *To zwierzę wymówiło swoja pierwsza głoskę/wypowiedziało trudne stowo.

Co istotne, zwierzę nie może pełnić funkcji ani agensa, ani adresata, jako roli implikowanej przez predykaty asertoryczne typu powiedzieć z włącznikiem $\dot{z} e-\mathrm{w}$ opozycji do predykatów cytacyjnych w rodzaju powiedzieć z dwukropkiem i myślnikiem (i z rolą adresata realizowaną przez analityczne dopełnienie w miejsce syntetycznego celownika), co sugeruje, że zwierzę, jakkolwiek częściej słyszy niż słucha, nierzadko człowieka (dosłownie) rozumie:

(62) *Pies powiedziat mi, że...

(63) *Pies powiedziat do mnie, że...

(64) Ten ptak powtarza/papuguje moje stowa., ale: *Ta papuga powiedziała mi/do mnie, że...

(65) *Adam powiedziat coś psu.

(66) *Adam powiedziat psu o czymś/na jakiś temat.

(67) *Adam powiedziat do psa o czymś/na jakiś temat.

(68) Adam powiedziat coś do psa.

(69) Adam powiedziat do psa: aportuj!, ale: *Adam powiedziat do psa, że ...

(70) *Adam powiedziat do Burka: ,daj łape” i Burek, chociaż nie wie, co to jest ,łapa”, podat mu łape. 
Ponieważ zwierzęta, w przeciwieństwie do ludzi, nie mówią, ale na swój sposób na pewno jakoś się ze sobą komunikują, sądzę, że rozsądnie będzie przyjąć to samo „komunikacyjne” kryterium jako podstawę do wyodrębnienia klasy zwierząt w środowisku przyrody ożywionej. Pozycję, jaką nasi bracia mniejsi zajmują w hierarchii stworzenia, odzwierciedla bowiem też nasz „komunikacyjny” stosunek do różnych jej przedstawicieli.

Organizmy komunikują się ze sobą: kontaktują i porozumiewają, przede wszystkim dzięki narządom percepcji, za pomocą których rejestrują te zachowania (własne i cudze), z którymi mogą wiązać (drogą asocjacji) określone intencje. Co jednak istotne, zwierzęta nie tylko (w sposób niekontrolowany) wydobywają z siebie rozmaite dźwięki (czy też może raczej dźwięki wydobywają się z nich), ale również (a może właśnie przede wszystkim) wydają z siebie głos w sposób najzupełniej zamierzony:

(71) To zwierzę wydało z siebie groźny głos.

a. *Burek szczeka, chociaż wcale tego nie chce.

b. *Gołębie nieumyślnie gruchaja.

c. *Kogut niechcacy zapiat.

Istnieje wręcz cała gama wyrażeń, które nazywają dźwięki, jakie wydają z siebie istoty żywe. Naturalnie, pod względem liczby tego rodzaju predykatów prym (w słowniku) wiodą ptaki, na drugim miejscu plasują się zwierzęta, a na końcu - inne stworzenia, m.in. gady, żaby i owady. (Szczegółową analizę tej ,zoosemiotycznej” partii leksykonu zostawiam na inną okazję).

Zwierzęta komunikują się ze sobą, z kolei ludzie komunikują się ze zwierzętami, wabiąc je przynętą lub głosem, a nawet przywołując (przyzywając) imieniem. Uważam, że subtelności, jakie dochodzą do głosu w związku z komunikacyjnym stosunkiem człowieka i zwierzęcia, mogą stanowić podstawę do wyodrębniania w klasie istot żywych kolejnych szczebli.

Zwierzęta wabią się nawzajem, zwłaszcza w kontekście rytuału zalotów; co jednak istotne: ludzie, imitując (w jakimś stopniu) te mechanizmy, na różne sposoby wołają i wabią do siebie zwierzęta oraz ptaki. Człowiek porozumiewa się więc ze zwierzętami, wabiąc je pokarmem i, co szczególnie ważne, głosem (Zaręba 1983: 193-206, szerzej: Siatkowska 1976):

(72) Ewa wabi gotębie ziarnem i gwizdaniem. 
Co jednak najistotniejsze z perspektywy prowadzonego przeze mnie wywodu, nie wszystkie stworzenia dają się przywoływać głosem, przeważająca część żywych istot reaguje zaledwie na przynętę:

(73) Ewa wabi tę suczkę/kotkę/kurkę/gaskę głosem., ale: *Ewa przyzywa tego węża/karpia/owada/robaka/wirusa głosem.

(74) Ewa wabi tego węża/szczupaka przynęta/na przynętę., ale: *Ewa wabi tego owada/robaka/wirusa przynęta/na przynętę.

O ile jednak każde głodne zwierzę zareaguje na widok pożywienia, o tyle nie każde (z natury rzeczy) zareaguje na określone dźwięki czy też swoje imię. Śmiem twierdzić, że dystynkcje te zaprowadzają na drabinie bytów pewien porządek (budują jakąś hierarchię).

Po pierwsze, ludzie i zwierzęta zawsze jakoś się nazywają (a jeśli ich nazwy nie są znane, to zwykle są domniemane; stąd biorą swój początek stereotypowe ich imiona), przy czym, co oczywiste, ludzie noszą imiona, z kolei zwierzęta się jakoś wabią (co znamienne, raczej unika się nadawania zwierzętom imion ludzkich, a ludziom - zwierzęcych):

(75) Ten chłopiec nazywa się Adam, a tamten pies - Burek.

(76) *Ten pies wabi się Burek, a tamten ptak/waż/owad/robak/wirus - jakoś podobnie.

(77) Ewa woła na psa: Burek., wobec: Ewa woła na niego: Adam.

(78) Ewa nawołuje/woła psa/Burka. oraz Ewa nawołuje/woła chtopca/ Adama.

(79) Ten chłopiec ma na imię Adam., ale: *Ten pies ma na imię Burek.

(80) Ten pies wabi się Burek., ale: *Ten chtopiec wabi się Adam.

(81) *Ten pies wabi się Adam. oraz *Ten chłopiec nosi imię Burek.

Co wymowne, do zwierząt nie zwracamy się, formułując ich imion w wołaczu, lecz zawsze - w mianowniku, co stanowi, w moim osądzie, pewien argument na rzecz tego, że zwierzęta są istotami (stworzeniami), ale nie osobami (por. komunikat w wołaczu stanowi apel nadawcy skierowany bezpośrednio do odbiorcy): 
(82) Azor/Burek, do nogi., ale: *Azorze/Burku, do nogi.

Rzecz jasna, zdarza się, że ludzie nadają imiona reprezentantom różnych gatunków zwierząt, często zresztą nieco na wyrost, wszak jedynie nieliczne spośród nich reagują na swoje nazwy. (Tego rodzaju sytuacji nie będę rozważał, sytuując je w obrębie tego, co określa się jako język w użyciu ludycznym).

Zwierzęta, nawet w przeciwieństwie do najbliższej sobie klasy ptaków, często komunikują ludziom swoje przywiązanie i oddanie, np. łasząc się do nas i liżąc różne części naszego ciała (co stanowi zawsze wyraźny komunikacyjny sygnał ich intencji i emocji):

(83) Burek tasi się do Ewy., ale: *Ewa tasi się do Burka.

(84) Zwierzęta łasza się do swoich opiekunów.

(85) 'Zwierzęta łasza się do siebie.

(86) *Zwierzęta łasza się do przedmiotów.

(87) *Te ptaki/węże/ryby/owady/robaki/bakterie łaszq się do kogoś/siebie.

(88) Burek polizał Ewę w rękę., czy nawet: Ewa polizała Burka w łapę., wobec: *Burek polizat krzesto w noge.

(89) To zwierze polizało moja rękę/mnie po ręce., ale: *Ten ptak/waż/ owad/robak/wirus polizat moja rękę/mnie po ręce.

W ten sposób zwierzęta, w przeciwieństwie do innych klas stworzeń, porozumiewają się (w elementarnym tego słowa znaczeniu) z nami (ludźmi), co jak sądzę stanowi kolejny (a może nawet koronny) argument na rzecz uznania tej (językowo realnej, tj. dającej się wyodrębnić za pomocą kryteriów językowo relewantnych) klasy za osobną gałąź na „drzewie życia”.

\section{Zakończenie}

Nie potrafię sobie wyobrazić języka ludzkiego, w którego leksykonie nie znajdowałyby się wyrażenia, jakie można by orzekać (wyłącznie) o organizmach żywych, takich jak zwierzęta i rośliny. We współczesnym języku polskim, co starałem się pokazać, można znaleźć mnóstwo językowych świadectw, które pozwalają wnioskować o miejscu, jakie zwierzęta zajmują na „drabinie bytów”. Przypomnę, że obiekt moich obserwacji stanowiły te pre- 
dykaty-orzeczenia, które dają się (sensownie i bezpośrednio) orzekać o zwierzętach, ale również - na zasadzie kontrapunktu - o ludziach i roślinach. Wierzę mocno w to, że skompletowanie i specyfikacja orzecznikowych dystynkcji umożliwi mi (w nieodległej przyszłości) udzielenie odpowiedzi na pytanie o architekturę rzeczywistości, czyli o to, jak ten świat jest urządzony, przynajmniej w tym zakresie, jaki wyznacza fascynujący i niezgłębiony cud życia.

\section{Bibliografia}

Aitchison J., 1991, Ssak, który mówi. Wstęp do psycholingwistyki, Warszawa: PWN. BogusŁawski A., 1988, Język w słowniku. Wrocław-Warszawa-Kraków-Gdańsk-Łódź: Zakład Narodowy im. Ossolińskich, Wydawnictwo Polskiej Akademii Nauk.

BogusŁawski A., 1996a, Logiczne, nielogiczne, pozalogiczne, Przeglad Humanistyczny 40/5, s. 109-142.

BogusŁawski A., 1996b, Świętość jakości życia?, Przeglad Humanistyczny 40/2, s. $1-38$.

BogusŁawski A., 1997, Do świata przez język, Przeglad Humanistyczny 41/2, s. 103-129 .

BogusŁawski A., 2001, O pozytywnej stronie granic poznania, w: A. Horecka, J. Jadacki (red.), U progu trzeciego tysiqclecia. Człowiek - Nauka - Wiara, Warszawa: Semper, s. 209-245.

BogusŁawski A., 2002, Światopogląd i wiedza (glosa do pewnej dyskusji), Przeglad Humanistyczny 46/2, s. 1-30.

BogusŁawski A., 2004, Rezygnacja i nadzieja filozofów, Przeglad Humanistyczny 48/2, s. 1-26.

Bogustawski A., 2007, A Study in the Linguistics-Philosophy Interface, Warszawa: BEL Studio .

Danielewiczowa M., 2002, Wiedza i niewiedza. Studium polskich czasowników epistemicznych, Warszawa: Katedra Lingwistyki Formalnej UW.

Duraj-Nowosielska I., 2007, Robić coś i coś powodować. Opozycja agentywności i kauzatywności w języku polskim, Warszawa: Wydział Polonistyki UW.

Gleason J. B., Ratner N. B., 2005, Psycholingwistyka, Gdańsk: Gdańskie Wydawnictwo Psychologiczne.

GrifFin D. R., 2004, Umysty zwierzat. Czy zwierzęta maja świadomość?, Gdańsk: Gdańskie Wydawnictwo Psychologiczne. 
Grochowski M., 1982, Zarys leksykologii i leksykografii. Zagadnienia synchroniczne, Toruń: Wydawnictwa UMK.

Grochowski M., 1993, Konwencje semantyczne a definiowanie wyrażeń językowych, Warszawa: Zakład Semiotyki Logicznej UW.

ISJP: BAŃKo M. (red.), 2000: Inny słownik języka polskiego, t. 1-2, Warszawa: PWN.

KrIPKE S., 2006, Nazywanie a konieczność, Warszawa: PAX.

MARKowsKi A., 1992, Leksyka wspólna różnym odmianom języka, Wrocław: Wiedza o Kulturze.

Mayr E., 2002, To jest biologia. Nauka o świecie ożywionym, Warszawa: Prószyński i S-ka.

Nowak T., 2012, Co to jest życie? Preliminaria semantyczne, Linguistica Copernicana 1(7), s. 191-208.

Nowak T., 2013, Od przesłanki do konkluzji. Polskie czasowniki wnioskowania, Katowice: Wydawnictwo Uniwersytetu Śląskiego.

SiATKOwsKa E., 1976, Zachodniosłowiańskie zawołania na zwierzęta (stan obecny, funkcje historyczne, stosunek do systemu językowego), Warszawa: Wydawnictwa Uniwersytetu Warszawskiego.

Spaemann R., 2001, Osoby. O różnicy między czymś a kimś, Warszawa: Oficyna Naukowa.

SS-G: PolańSKi K. (red.), 1980-1992, Słownik syntaktyczno-generatywny czasowników polskich, t. 1-5, Wrocław-Warszawa-Kraków: Instytut Języka Polskiego PAN.

USJP: Dubisz S. (red.), 2003, Uniwersalny słownik języka polskiego, t. 1-6, Warszawa: PWN.

Wierzbicka A., 1970, Semantyka zdań o zwierzętach, Pamiętnik Literacki, z. 1, S. 199-218.

WierzBicka A., 1993, Nazwy zwierząt, w: J. Bartmiński, R. Tokarski (red.), O definicjach i definiowaniu, Lublin: Wydawnictwo Uniwersytetu Marii Curie-Skłodowskiej, s. 251-267.

WierzBickA A., 2006, Semantyka. Jednostki elementarne i uniwersalne, Lublin: Wydawnictwo Uniwersytetu Marii Curie-Skłodowskiej.

ZaręBA A., 1983, Pisma polonistyczne i slawistyczne, Warszawa-Kraków: Państwowe Wydawnictwo Naukowe.

ZAron Z., 1998, Czy zwierzę to ktoś? Językowe dowody podmiotowości zwierząt, Prace Filologiczne, t. 43, s. 507-515.

Zaron Z., 2009, Problemy składni funkcjonalnej, Warszawa: Wydział Polonistyki UW.

Zaron Z., 2011, Ktoś to znaczy kto? O językowym statusie roślin, Poradnik Języko$w y$, z. 1, s. 121-130. 
Who or what an animal ('zwierzę') is, and who or what is an animal ('zwierzęciem')? A couple of linguistic remarks

\section{( su m mary)}

So far the term used in the title has not been an object of a more extensive linguistic reflection. The author of this paper aims at providing a thorough description of the lexical unit zwierze with respect to its meaning and collocations. In the opinion of the author, the results obtained indicate the location of animals on the scala naturae. 